\title{
Assessment of Stigma Exposure Status of Patients with Hepatitis B Infection
}

\section{Hepatit B Enfeksiyonu olan Hastalarda Yașanılan Zorlukların Değerlendirilmesi}

\author{
๑ Illknur Esen Yıldız¹, ๑ llkkay Bahçeci², ๑ Ayten Yılmaz Yavuz³, ๑ Uğur Kostakoğlu¹, ๑ Ayşe Ertürk1 \\ ${ }^{1}$ Recep Tayyip Erdoğan University Faculty of Medicine, Department of Infectious Diseases and Clinical Microbiology, Rize, Turkey \\ ${ }^{2}$ Recep Tayyip Erdoğan University Faculty of Medicine, Department of Medical Microbiology and Clinical Microbiology, Rize, Turkey \\ ${ }^{3}$ Recep Tayyip Erdoğan University Vocational School of Health, Department of Public Health Nursing, Rize, Turkey
}

\begin{abstract}
Objectives: Although stigma is well defined in people with a chronic disease or condition, it has not been studied much in individuals infected with hepatitis B virus (HBV). The study is one of the first descriptive individual studies conducted on this subject in our country. Our aim in this study was to evaluate the stigma experiences and concerns of individuals living with HBV, their sharing of their illness with the environment, and the state of being affected by their social relationships.

Materials and Methods: Patients with hepatitis B surface antigen positivity who were admitted to the infectious diseases outpatient clinic were surveyed through face-to-face interviews. Epidemiological data, stigma experiences and anxiety states, people with whom they shared their illness, the reasons for not sharing, the impairment of social relations were questioned.

Results: It was found that $19.5 \%$ of 390 individuals infected with HBV who participated in our study were "exposed" to stigma in various ways, and $27.4 \%$ were "worried" about experiencing this condition. In research, $19.9 \%$ of women, $41.4 \%$ of university graduates, and $34.8 \%$ of divorced or widowers were found to experience higher stigma $(p=0.002, p=0.02$ and $p<0.001$, respectively). It was determined that $56.7 \%$ of the participants did not share their illnesses, and this need increased with stigma experiences and anxiety. It was found that individuals mostly shared their disease status with their first-degree relatives $(p<0.001)$.

Conclusion: The fact that individuals infected with HBV experience different forms of stigma or experience anxiety suggests that there is a need to investigate these conditions and develop treatment interventions.

Keywords: Hepatitis B infection, stigma, awareness
\end{abstract}

\section{ÖZ}

Amaç: Stigma, kronik hastalığı veya durumu olan kimselerde iyi şekilde tanımlanmış olmasına rağmen hepatit $B$ virüsü (HBV) ile enfekte bireylerde çok fazla araştırımamıştır. Çalışma bu konu hakkında ülkemizde yapılan ilk tanımlayıcı bireysel çalışmalardan biridir. Bu çalışmada amacımız, HBV ile yaşayan bireylerin stigma deneyimleri ve kaygılarının, hastalıklarını çevreyle paylaşma ve sosyal ilişkilerinin etkilenme durumunun değerlendirilmesidir.

Gereç ve Yöntemler: Enfeksiyon hastalıkları polikliniğine başvuran hepatit B yüzey antijeni (+) bireylerle yüz yüze görüşme yoluyla anket yapıldı. Epidemiyolojik veriler, hastaların stigma deneyimleri ve kaygı durumları, hastaların hastalıklarını kimlerle paylaştıkları, paylaşmama nedenleri ve sosyal ilişkilerin etkilenmesi sorgulandı.

Bulgular: Çalışmamıza katılan HBV ile enfekte 390 bireyin \%19,5'inin çeşitli şekillerde stigmaya "maruz kaldığı", \%27,4'ünün ise bu durumu yaşamaktan "kaygı duyduğu" bulundu. Araştırmada kadınların \%19,9'unun, üniversite mezunlarının \%41,4'ünün, boşanmiş/dul olan bireylerin \%34,8'inin daha yüksek oranda "stigma" yaşadığı belirlendi (sırasıyla; $p=0,002, p=0,02$ ve $p<0,001$ ). Katılımcıların \%56,7'sinin hastalıklarını paylaşmadığı, stigma deneyimleri ve kaygı durumuyla birlikte bu intiyacın arttığı belirlendi. Bireylerin hastalık durumlarını en çok birinci derece yakınları ile paylaştıkları tespit edildi $(p<0,001)$.

Sonuç: HBV ile enfekte bireylerin farklı șekillerde stigma deneyimleri veya kaygı yaşadıklarının tespit edilmiş olması, bu durumların araştırıması ve iyileştirme müdahalelerinin geliştirilmesine intiyaç olduğunu düşündürmüştür.

Anahtar Kelimeler: Hepatit B enfeksiyonu, stigma, farkındalık

Yıldız IE, Bahçeci I, Yılmaz Yavuz A, Kostakoğlu U, Ertürk A. Assessment of Stigma Exposure Status of Patients with Hepatitis B Infection. Viral Hepat J. 2021;27:80-88. 


\section{Introduction}

Hepatitis B virus (HBV) infection is a global public health problem and continues to be important $(1,2,3)$. According to the report of the World Health Organization (WHO), it is reported that one million people die every year due to viral hepatitis, and since 2000 there has been an increase of $22 \%$ in deaths. WHO aims to reduce the number of HBV infections by $90 \%$ and mortality by $65 \%$ for 2030 and determines strategies for this purpose. One of these strategies is to ensure that individuals are diagnosed by generalizing HBV examinations and to prevent social transmission by treating them when necessary $(4,5,6,7)$. However, the situation or anxiety of individuals encountering stigma in various ways in their environment due to being diagnosed with HBV may create some obstacles in ensuring the success of these strategies.

These unpleasant conditions, which are assessed in different conditions and patients, have not been studied much in HBVinfected individuals $(8,9,10,11)$. Stigma (stigmatization, labeling); is a social unacceptance situation and has been expressed in various ways. On the one hand, it is defined as a social and cultural process, on the other hand, it is considered as a state of deviation from normal and a complex individual/social time period $(12,13)$. Stigma may be associated with feelings of shame, blame, fear, anxiety, depression, and lower quality of life ( $\mathrm{HCQ}$ ) among people living with chronic hepatitis B (CHB). Stigma against individuals can also appear as discrimination. Discrimination, on the other hand, has been stated by the institutions as negative actions such as refusing the employment of people with certain characteristics and preventing access to health services, with basic concepts such as race and sexuality at the forefront. It has been reported that negative attitudes and behaviors towards individuals can be seen in many environments such as family, relatives, immediate environment, social environment, work environment, and health institutions $(8,13,14,15,16)$. The state of anxiety is a situation that occurs with the threat or perception of a threat of body or mind that is real or imaginary and it can be frequently observed in individuals with chronic infections (17).

Some of the individuals with HBV infection because of their anxiety about exposure to stigma in various ways or encountering this situation; they do not have screening or diagnostic tests, they need to hide their diseases, and even some of those who are diagnosed do not have their treatment and follow-up $(10,11,18,19)$. Depending on these situations, patients can both endanger their own health and play a role in social contagion by causing the spread of infection. Individuals may also present with late complications of HBV infection, such as hepatocellular cancer, cirrhosis, and liver failure, due to delays in treatment $(3,20)$.

Our aim is to assess the experiences of stigma or anxiety in patients with HBV infection, the reasons for sharing or not sharing their HBV infection, their social relations, and knowledgeawareness in our own clinic. The study is a pilot study that also aims to control and determine the obstacles to the disease in individuals living with HBV.

Our aim is to assess the experiences of stigma or anxiety in patients with HBV infection, the reasons for sharing or not sharing their HBV infection, their social relations, and knowledgeawareness in our own clinic. The study is a pilot study that also aims to control and determine the obstacles to the disease in individuals living with HBV.

\section{Materials and Methods}

\section{Study Design and Setting}

The study was conducted as a descriptive cross-sectional study at Recep Tayyip Erdoğan University Faculty of Medicine and Training and Research Hospital between 2018-2020, with faceto-face interviews with HBV infected individuals who applied to the infectious diseases and clinical microbiology outpatient clinic, who agreed to participate in the questionnaire. The patients were informed in detail about the study. After the questionnaire patients were informed by the Guidelines for Prevention and Treatment of $\mathrm{CHB}$.

\section{The Criteria for Inclusion in the Study}

Volunteer patients aged 18 years or older who were infected with HBV were included. Individuals with hepatitis B surface antigen (HBsAg) (+), HBV-DNA level 2,000 IU/mL and below were accepted as HBV carriers, and those with 2,000 IU/mL and above as chronic HBV infection.

\section{Instruments-data Collection}

The questionnaire questions were developed depending on the literature $(8,10,21)$. The questionnaire was composed of questions questioning the demographic characteristics of the patients (age, gender, education, place of residence, marital status, alcohol, cigarette or drug addiction, stage and duration of the disease, presence of HBV infection in the family, knowledge of the transmission routes and complications of HBV infection), the status of sharing their illnesses due to being diagnosed with HBV infection, the reasons for not sharing, their life experiences due to stigma-discrimination, and their anxiety. Verbal consent was obtained from the participants by explaining the content of the study before the questionnaire. The questions in the study were divided into groups as sharing the disease behavior, experiencing stigma discrimination, or anxiety due to the disease, and social relations (answers were arranged according to the 4-point Likert scale).

\section{Ethics}

Before starting the study, written permission from the institution their search was conducted in, and approval from Recep Tayyip Erdoğan University Non-Invasive Clinical Researches Ethical Board (decision number: 2020/129) were taken.

\section{Statistical Analysis}

The data of the study were assessed with IBM SPSS 23.0 (Chicago, USA) software. The compliance of the variables to normal distribution was checked with the Kolmogorov-Smirnov test. Descriptive statistics (percentage, frequency, median) and chisquare analysis were used to assess the data. Statistically $p<0.05$ was taken as the significance level.

\section{Results}

Of the 390 patients included in the study; $51.5 \%$ were women $(n=201)$, the median age was $42(19-98)$ years, and the median 
duration of the disease was found to be $10(1-35)$ years. It was determined that $77.2 \%(n=301)$ of the participants were married, $50 \%(n=195)$ had primary school education and 39.5\% ( $n=154)$ lived in the city center, and $73.6 \%(n=287)$ had HBV in their families. Demographics details of the participants are given in Table 1. When the transmission routes are questioned to assess the knowledge of individuals infected with HBV, it was determined that $10.5 \%(n=41)$ of the participants did not know that virus is transmitted by blood, $7.9 \%(n=31)$ by sexual transmission, 30.8\% $(n=120)$ by vertical transmission from mother to baby, $6.2 \%(n=24)$ of the participants did not know that the virus could be transmitted with the special items used in the nail clipper-barber, 37.4\% $(n=146)$ with the use of common items such as plates, glasses, forks. It was found that $92.8 \%(n=362)$ of the individuals did not know about the disease before being infected with HBV, 17.9\% $(n=70)$ did not know that the disease could progress to cirrhosis and $43.1 \%(n=168)$ did not know that the disease could turn into hepatocellular cancer.

When the participants' sharing status of their sickness was assessed according to their epidemiological characteristics, while the highest share rate in all groups was determined as with family members, first degree relatives (mother, father, spouse, and children) with $99.2 \%(n=388)$, the least sharing rate was determined as with work/social environment with $60 \%(n=232)$. In terms of gender, it was observed that females shared their status at a higher rate than males and that they most often said to their first-degree relatives, and it was found to be statistically significant $(p=0.03)$. While no statistically significant difference was observed in the fields of education and profession regarding sharing the illness with their relatives, a statistically significant difference was observed in the place of residence and marriage status (p-values: $0.14,0.35,0.04,0.03$, respectively). The epidemiological characteristics of the individuals and the distribution and statistical comparison of the people with whom they share the diagnosis of HBV infection are given in Table 2. It was determined that 34 of the individuals living with HBV shared their illness with everyone around them and the others were selective. It was determined that all participants shared their disease status mostly with their first degree relatives and it was found to be statistically significant $(p<0.001)$.

HBV infected individuals were divided into three groups according to their stigma exposure; was determined that the first group ( $n=76$ and 19.5\%) was "exposed" to stigma in various ways, the second group ( $\mathrm{n}=107$ and $27.4 \%$ ) did not experience this situation but felt anxiety, and the third group ( $n=207$ and $53.1 \%)$ did not experience any of these situations. Sharing status of the patients according to their situation of treating with stigma is given in Table 2. When the participants' non-sharing of HBV infections were examined, it was found that two patients did not share their illness with anyone (231 and 59.2\%), and they did not share their illness with various individuals around the participant. The reasons for not sharing were roughly grouped into 3 groups; it was determined for the first group ( $n=76$ and 19.5\%) as "being exposed to at least one of various stigma conditions", for the second group as anxiety of being exposed to at least one of the stigma states ( $\mathrm{n}=107$ and $27.4 \%$ ), and for the third group as no need to say-not wanting to others to know the special condition ( $\mathrm{n}=48$ and $12.3 \%)$.

Among the participants, $19,9 \%(n=40)$ of women, $41,4 \%$ of university graduates $(n=12)$, and $34,8 \%$ of divorced or widower $(n=24)$ were found to experience higher stigma related victimization, which was statistically significant $(p=0.002, p=0.02$ and $p<0.001$,

Table 1. Demographic characters of the participants

\begin{tabular}{|c|c|c|c|c|c|}
\hline & $\mathrm{n}$ & $\%$ & & $\mathrm{n}$ & $\%$ \\
\hline \multicolumn{3}{|l|}{ Gender } & \multicolumn{3}{|l|}{ Education } \\
\hline Male & 189 & 48.5 & Illiterate & 67 & 17.2 \\
\hline \multicolumn{3}{|l|}{ Profession } & High school & 99 & 25.4 \\
\hline Officer & 52 & 13.3 & University & 29 & 7.4 \\
\hline Housewife & 164 & 41.8 & District & 148 & 37.9 \\
\hline Unemployed & 72 & 18.5 & \multirow{2}{*}{ Village } & \multirow{2}{*}{88} & \multirow{2}{*}{22.6} \\
\hline Student & 9 & 2,3 & & & \\
\hline \multicolumn{3}{|l|}{ Marital status } & \multicolumn{3}{|c|}{ Having family member with hepatitis } \\
\hline \multicolumn{3}{|l|}{ Stage of diseases } & \multicolumn{3}{|c|}{ Who is aware of the disease? } \\
\hline Inactive carriers & 343 & 87.9 & Parents/spouse/child & 388 & 99.2 \\
\hline Chronic active hepatitis & 45 & 11.5 & Relative/neighbor & 291 & 74.4 \\
\hline $\begin{array}{l}\text { Cirrhosis and hepatocellular } \\
\text { cancer }\end{array}$ & 2 & 0.6 & Coworker/social friend & 232 & 60.0 \\
\hline
\end{tabular}


Table 2. The epidemiological characteristics of the participants and the distribution of the people with whom they shared their diagnosis of HBV infection*

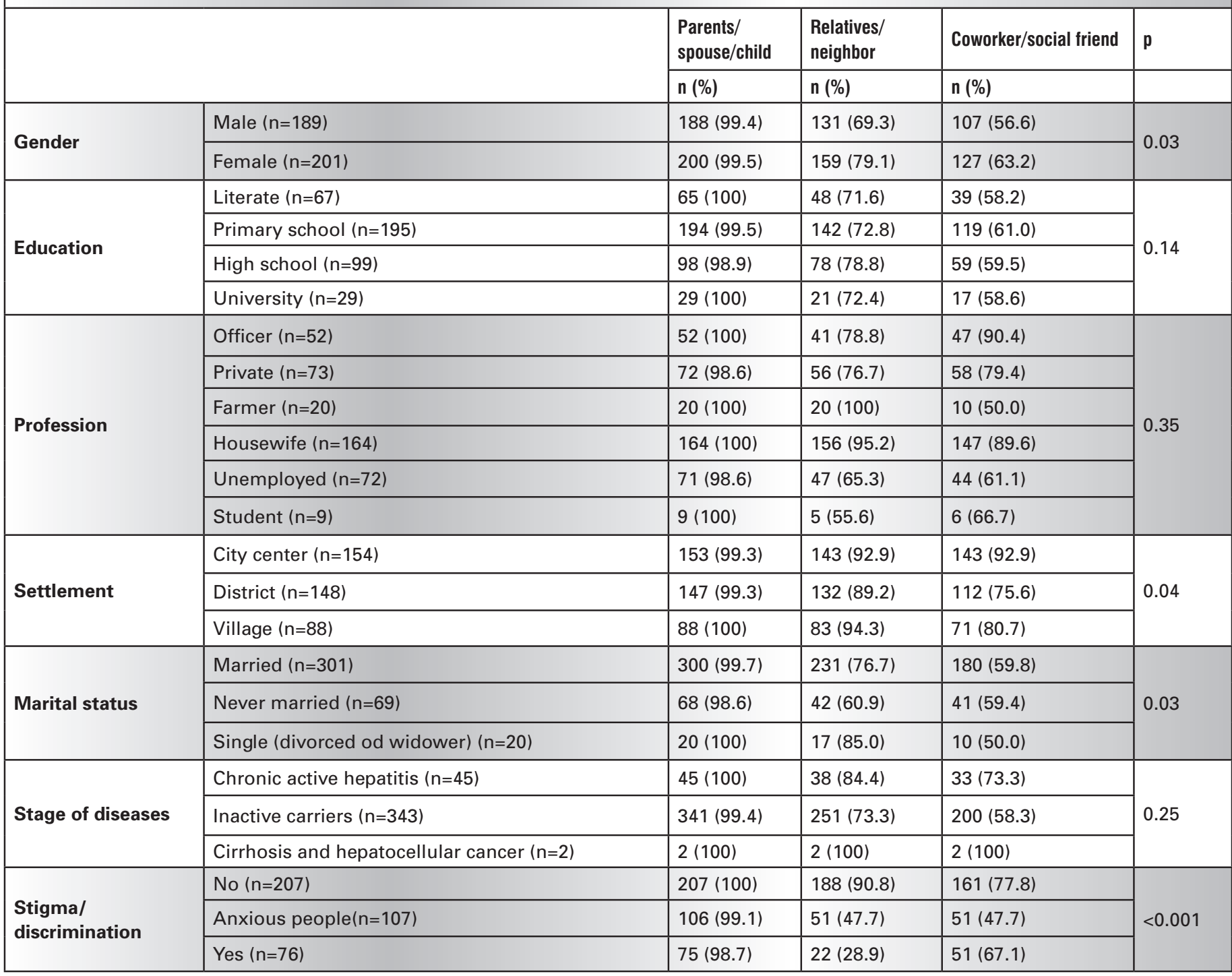

respectively). The relation of stigma/experiencing discrimination with epidemiological data is given in Table 3.

When the exposure situations are investigated to private level, they found as experiencing at least one of the situations of "being excluded from the environment, getting reaction, being deceitful, embarrassed, judged" ( $n=28$ and $34.2 \%$ ), people staying away from themselves ( $n=6$ and $7.9 \%$ ), not eating their meals, plates fork-spoon ( $n=10$ and 13.2\%), not being admitted to a dormitory ( $n=4$ and $5.2 \%$ ), not being hired or being fired ( $n=28$ and $34.2 \%$ ). Absence of employment and dismissal status was determined as not being hired as a cook ( $n=10$ and 35.7\%), not being asked to act as a babysitter ( $n=8$ and $28.6 \%$ ), not being admitted to a police school ( $n=7$ and $25 \%$ ), not being hired as a cleaning staff ( $n=3$ and 10.7\%).

When the anxiety states of the participants based on their experiences are examined, the presence of "anxiety about transmitting the disease to someone else, anxiety that the person to marry will experience discrimination due to the disease" ( $n=142$ and $36.4 \%, n=107$ and $27.4 \%$ ) with the highest frequency, respectively and the least frequently "anxiety about discrimination while receiving health care" were found ( $n=324$ and $83.1 \%$ ). The variables related to the anxiety states of individuals infected with HBV and the data regarding the influence of social relations are given in Table 4.

In the study, it was found that HBV-infected individuals were most frequently affected by coworker relationships $(n=30$ and $26.1 \%)$.

\section{Discussion}

Stigma has been frequently investigated in patients with physical-mental disorders, drug addiction, alcoholism, tuberculosis, HIV and HCV, etc. chronic diseases $(9,11,18,22)$. However, studies conducted in patients with HBV infection are less worldwide $(8,23,24,25)$. Studies conducted in our country are limited in number and are not investigated alone in individuals living with HBV $(23,24,25)$. In the study we conducted in order to see the profile of HBsAg (+) people in Rize province and to determine the problems 
Table 3. Analysis of patients exposed to stigma/discrimination according to their epidemiological characteristics

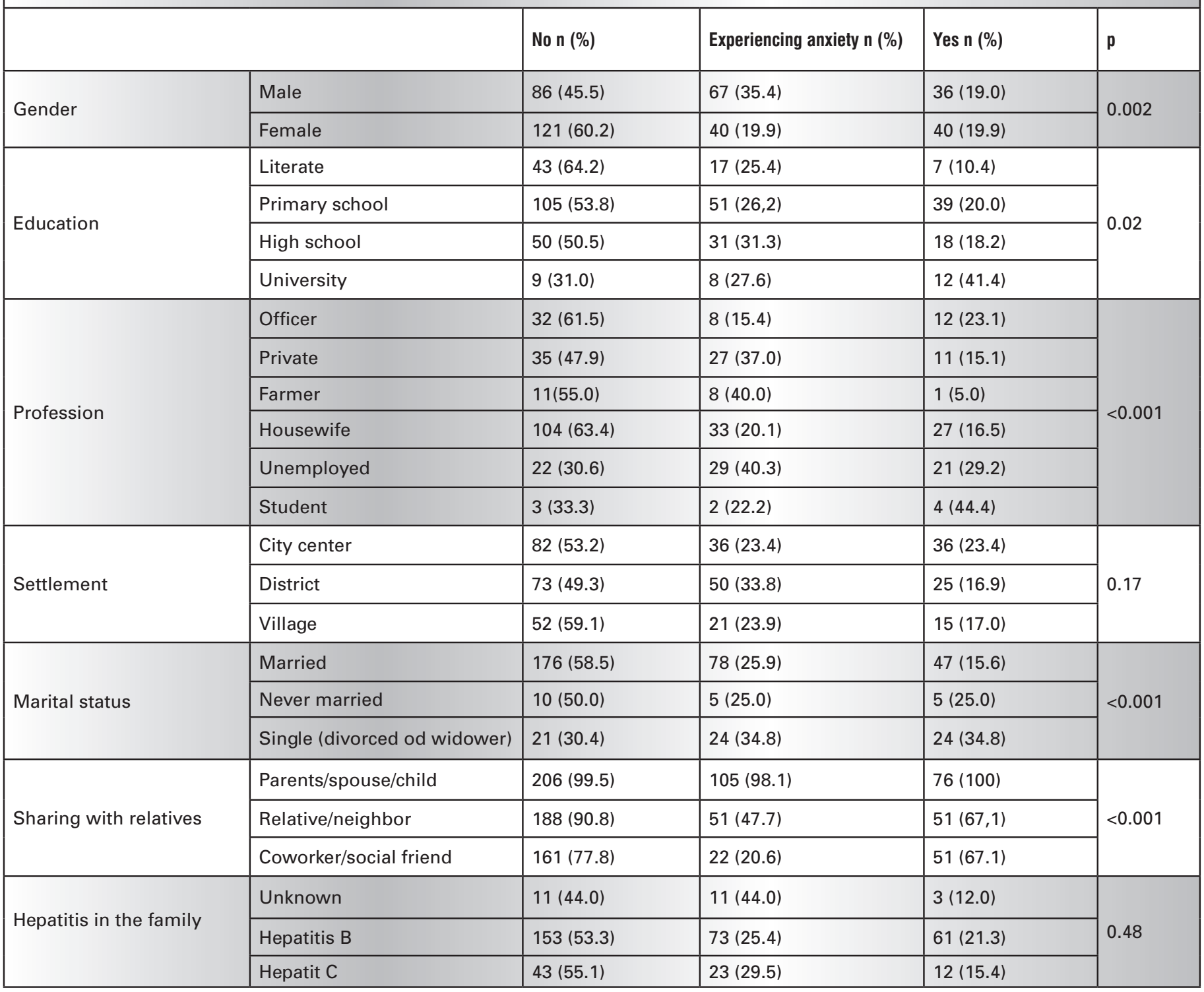

and deficiencies, it was determined that exposure to stigma in our patients was not at all low. This situation made us think that stigma should be cared for in individuals living with HBV in the society and solutions should be investigated.

In the society in studies; it has been stated that stigma can be observed in many different situations such as exclusion, stigmatize, discrimination, disclosure, rejection, accusation, trial, stigma, distancing, reaction, etc $(8,11,26,27,28)$. In addition, it has been reported that there are victimizations in different areas, especially in social relations, access to health services, education and business environment $(9,10,26,27,29,30,31)$. In the study of Tran (32), it was found that the treatment management of patients due to being late due to stigma anxiety became difficult, in the review of Ellard and Wallace (18), indigenous Australian people did not have screening and diagnostic tests due to prejudices, did not take protective measures, and did not have the HBV vaccine sufficiently. These patients may come up with late complications of the disease in the future. WHO reported that at least $60 \%$ of liver cancer cases developed due to delay in treatment due to the failure of performing hepatitis diagnosis tests on time $(3,20)$. In our study, the majority of the patients stated that they did not have information about HBV infection before diagnosis, so the absence of a test due to stigma could not be examined. The fact that they were not asked whether the follow-up and treatment status due to stigma were disrupted after the diagnosis was seen as an important limitation of our study.

In studies, it was stated that individuals often tend not to share their diseases in order to avoid any exposure related to stigma $(19,21,28,33,34)$. Mohamed et al. (30) reported that $33.5 \%$ of HBV-infected individuals hesitated to explain their disease in order not to experience stigma and $93.6 \%$ of them shared their condition only with their families. Wallace et al. (27) found in their investigations that participants selectively shared their infection status to protect themselves and their families. In our study, it was 
Table 4. Participants' anxiety and life experiences due to being diagnosed with hepatitis $B$

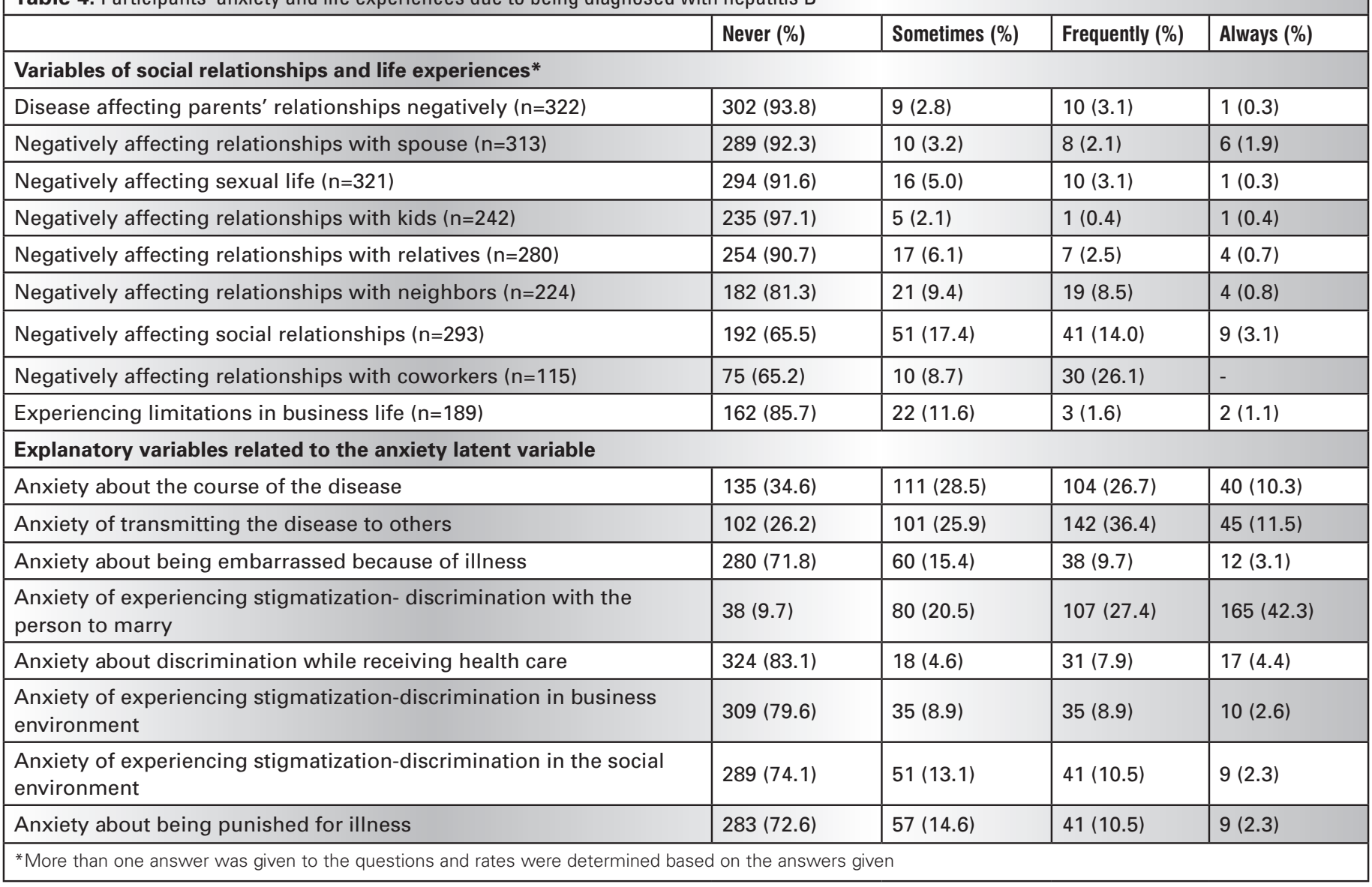

determined that the participants were selective when sharing their diseases, $25.6 \%$ of them did not share their disease information with their close relatives and neighbors, $40 \%$ with their work and social environment, and two people did not share their disease information with anyone.

In our study, it was found that individuals who were both exposed to stigma and experienced exposure anxiety tend not to share their illnesses frequently. Among the reasons for not sharing, not being hired or dismissed situation or anxiety came to the fore and this situation brought to mind the necessity of raising awareness and prioritizing improvement on this issue. Similar to our study, it was observed that this situation is at the top of the exposures outside of our country. In most of the studies, it has been reported that one of the places where individuals share their illness the least is the work environment and it has been stated that individuals generally avoid disclosing that they are infected due to reasons such as not being hired or being fired $(8,10,21,30,33,35,36)$. This situation made us think that stigma may cause material and moral problems in individuals infected with $\mathrm{HBV}$, and this situation should be considered.

Studies have shown that the degree of stigma experiences and the areas affected by them may show a social difference, and their exposure may be more common among certain populations, epidemiologically, culturally, religiously, and ethnically $(9,11,18,27,36)$. Despite the national HBV anti-discrimination laws and regulations in China, stigma-based discrimination continues to be widespread in many settings, including patients living with $\mathrm{CHB}$, the workplace, educational institutions, healthcare centers, and the community (21). In another study performed, it was reported that 29\% of Vietnamese living in Chicago thought that people with HBV could be discriminated against at work, at school, and $21 \%$ of them believed that HBV carriers could be denied health services (8). The stigma was also observed in the statements of the participants in our study, where the patients were exposed to negative behaviors such as not being eaten from the food they cooked, avoiding hugging, not being cared for babies, not being asked to be employed, getting away from them, not being taken to the dormitory. However, unlike other studies, this exposure has been found to be quite low in healthcare services.

In our country, it was not possible to assess the situation, since there is no study in which stigma was examined and studied alone in individuals infected with HBV in our country. In the study we conducted in our own province, it was determined that $19.5 \%$ of the participants were exposed to at least one of the stigmadiscrimination situations in various ways and these people shared less of their illness with their environment, and it was found to be statistically significant $(<0.001)$. In addition, another important point that draws our attention is that the participants' anxiety about being exposed to stigma-discrimination was found to be higher than their exposure. When asked about the concerns of individuals infected with HBV, the fact that it was determined that the anxiety of transmitting the disease to other individuals came to the fore, may 
have contributed primarily to this situation. However, the limitation of our study is that only HBV-infected patients were assessed and that the knowledge and attitudes of those living around them were not examined. It is thought that studies conducted with the participation of all individuals, whether infected or not, would put the problems experienced better.

In the literature, it has been stated that the stigmadiscrimination against individuals with $\mathrm{HBV}$ is mostly related to the lack of knowledge and awareness about the transmission routes, prevention and treatment of the infection $(8,11,20,28)$. In a study conducted in Ghana, it was observed that the opinion that the patients were "cursed" due to their religious beliefs was prevalent due to the thought that HBV infection caused a highly contagious, severe disease and it was not known that there was a treatment (36). Again, in studies conducted in Canada and China, it has been reported that the information on the transmission routes of HBV is not very good. In the questionnaire study applied to all Vietnamese living in Chicago, it was reported that $44 \%$ of the participants stated that individuals infected with HBV should avoid close contact such as hugging or kissing. Again, in some studies performed, it was determined that the patients and the people around them avoid physical contact, daily activities, avoid sharing their food and belongings, etc., and experience discriminationexposure $(8,9,21,33)$.

It has been reported that awareness about hepatitis infection in our country is not very good, with a low rate of $12 \%$ (6). In our study, the fact that it was determined that $92.8 \%$ of the individuals did not have an idea about the disease before they were infected, although there was a very large family history in the participants, and when the individuals were surveyed, $146(37,4 \%)$ of them stated that they had hepatitis contagiousness even in situations such as food sharing and use of common items, and 120 (30.8\%) of them were not known to be transmitted from mother to baby, and the awareness of other transmission routes was not found to be $100 \%$, showed that awareness and consciousness were not very good in our own patients. However, since our study was conducted only on individuals infected with HBV and not on noninfected individuals, it cannot be generalized to the whole society. This is an important limitation of our study, and it made us think that studies involving all individuals should be conducted. Identifying the deficiencies as a society and applying educational interventions without discriminating individuals can be much more beneficial for the improvement of awareness and consciousness.

Studies examining the relationship between educational status and experiencing one of the stigma states in HBV-infected patients are limited in the literature. In a study conducted among immigrants in Beijing, although there is an inverse relationship between high education level and stigma-discrimination, different studies reported that stigma-discrimination anxiety increases as the education level increases $(8,10,21,33)$. The fact that it was found in our study that the most stigma-discriminated people were university graduates and that these people had difficulties in getting a job made us think that there were serious insufficiencies in the approach to individuals with HBV infection in the society and the need to take some legal measures.

In the studies, it was found that individuals do not want to have a screening test for hepatitis B infection because they are afraid of being deprived of social isolation due to information poverty in countries with poor immigrants, especially in communities with low education levels $(8,31,35)$. In the observational study of $\mathrm{Vu}$ et al. (37), they stated that Chinese and Vietnamese immigrants did not want to have a screening test due to many reasons such as not being able to find a job, not being able to rent a room, not being able to make friends because they live together in small rooms, they are reluctant to tell about their diseases, and vaccination rates are low. It is very important for individuals infected with HBV to be afraid of getting diagnosis or to hide their diseases after diagnosis, not to follow-up and treatment, as well as endangering their own health as well as spreading the virus and causing public transmission. Especially in people living as immigrants, the presence of a contagious infectious disease may trigger exposure to stigma. The rate of immigrants in our province is very low and there is no immigrant participant in our study. Since our country has been receiving immigrants quite frequently in recent years, it can be better assessed whether cultural and linguistic differences affect stigma and discrimination by planning studies in which these groups would include.

In the study, it was found that individuals infected with HBV are exposed to stigma in various ways, especially opportunities such as recruitment, and their awareness and consciousness are not very good. However, it is thought that the stigma was not observed prominently in all areas of the society would be related to individuals' selectively sharing their diseases with their environment or hiding their diseases.

Determining the difficulties experienced in individuals with HBsAg (+) may contribute to HBV prevention strategies. Access to HBV screening and diagnostic tests, vaccination and preventive standard methods should be increased, and development of the complications should be prevented by treating patients. Countries should determine the stigma situations that will affect each of these steps separately according to their ethnic structure, and take relevant measures to ensure recovery. In line with this purpose, efforts should be made to reach accurate and accessible information to the whole society through training seminars, press and media, and efforts should be made to raise awareness with legal protection, treatment and support systems throughout the country and to improve the health and well-being of individuals.

\section{Study Limitations}

The study is performed in tertiary hospital in a province of the Eastern Black Sea region of Turkey, Rize and not all HBV infected individuals in the province were reached. In the study, only the stigma status in infected individuals was examined, and other causes affecting the quality of life, such as depression, were not investigated. Other limitations of the study include the absence of a case-control group and the lack of use of a scale. It is thought that there is a need for randomized controlled studies that reflect the country in which the number of data is much higher. The difficulties and adverse situations experienced have been investigated only in people living with HBV and cannot be generalized to the whole society. It was thought that assessing the studies that investigated the perspective and knowledge levels of the people around the infected individual would be more beneficial for educational interventions and raising awareness. 


\section{Positive Aspects}

As far as we know, the study is the first descriptive study in our country in which only stigma was investigated in individuals infected with HBV, and it is a pilot study conducted to reveal the problems experienced in our city. Identifying deficiencies can be helpful in planning regulations. However, multi-center studies should be planned and supported by studies reflecting the country in general.

\section{Conclusion}

It has been observed that stigma is not negligible in hepatitis $B$ infection, and it persists at various levels in individuals infected with HBV. It is thought that there is a need for plannings that reflect the society in general, include different ethnic groups, identify problems and carry out solution-oriented public works, and provide consultancy services.

\section{Ethic}

Ethics Committee Approval: Before starting the study, written permission from the institution their search was conducted in, and approval from Recep Tayyip Erdoğan University NonInvasive Clinical Researches Ethical Board (decision number: 2020/129) were taken.

Informed Consent: Verbal consent was obtained from the participants by explaining the content of the study before the questionnaire.

\section{Peer-review: Externally peer-reviewed.}

\section{Authorship Contributions}

Concept: I.E.Y., I.B.., Design: I.Y.E., U.K., A.E., Data Collection or Processing: A.Y.Y., U.K., Analysis or Interpretation: A.Y.Y., Literature Search: U.K., A.E., Writing: I.E.Y., I.B., U.K., A.E.

Conflict of Interest: The authors of this article declare that they have no conflict of interest.

Financial Disclosure: The authors declare that this study has not received any financial support.

\section{References}

1. World Health Organization. Guidelines for the prevention, care, and treatment of persons with chronic hepatitis B infection. Geneva: 2015

2. Li T, Su S, Zhao Y, Deng R, Fan M, Wang R, Sharma M, Zeng H. Barriers to the Prevention and Control of Hepatitis B and Hepatitis $C$ in the Community of Southwestern China: A Qualitative Research. Int J Environ Res Public Health.2019;16:231.

3. Wada K, Smith DR, Ishimaru T. Reluctance to care for patients with HIV orhepatitis $\mathrm{B} / \mathrm{C}$ in Japan. BMC Pregnancy Childbirth 2016;16:1-6.

4. Terrault NA, Lok ASF, McMahon BJ, Chang KM, Hwang JP, Jonas MM. Update on prevention, diagnosis, and treatment of chronic hepatitis B: AASLD 2018 hepatitis B guidance. Hepatol 2018;67:1560-1599

5. European Association For The Study Of The EASL clinical practice guidelines: Management of chronic hepatitis B virus infection. J Hepatol 2012;57:167-185.

6. Association for the Fight Against Viral Hepatitis. Turkey Viral Hepatitis Diagnosis and Treatment Guide 2017.

7. World Health Organization. Global hepatitis report, 2017

8. Dam L, Cheng A, Tran P, Wong SS, Hershow R, Cotler S, Cotler SJ. Hepatitis B Stigma and Knowledge among Vietnamese in
Ho Chi Minh City and Chicago. Can J Gastroenterol Hepatol 2016;2016:1910292.

9. Hassanpour DA, Mohammadi N, Nikbakhat NA. Hepatitisrelatedstigma in chronicpatients: A qualitative study. Appl Nurs Res 2016;29:206-210.

10. Yu L, Wang J, Zhu D, Leng A, R Wangen K. Hepatitis B-related knowledge and vaccination in association with discrimination against Hepatitis B in rural China. Hum Vaccin Immun 2016;12:70.

11. Tingting L, Shu Su S, Yong Z, Runze D, Mingyue F, Ruoxi W, Manoj S. Barriers to the Prevention and Control of Hepatitis B and Hepatitis C in the Community of South western China: A Qualitative Research. Int J Environ Res Public Health 2019;16:231.

12. Scambler G. Health-related stigma. Sociology of Health\&lllness 2009;31:441- 455.

13. Goffman E. Stigma: notes on the management of social spoilted identity. Eaglewood Cliffs, NJ@ Prentice-Hall; 1963.

14. Porter NB. Special Treatment Stigma after the ADA Amendments Act. Pepperdine Law Review, Forthcoming; University of Toledo Legal Studies Research Paper No.201508; 2015;43(2).

15. Australasian Society for HIV, Viral Hepatitis and Sexual Health Medicine. Stigma and discrimination around HIV and HCV in healthcare Settings: research report. Sydney; 2012.

16. Han B. The experience of discrimination of individuals living with chronic hepatitis B in four provinces of China. PLoS One 2018;13:e0195455.

17. Lieber E, Li L, Wu Z, Rotheram-Borus MJ, GuanJ . The National Institute of Mental Health (NIMH) Collaborative HIV Prevention Trial Group.HIV/STD stigmatization fears as health-seeking barriers in China. AIDS Behav 2006;10:463-471.

18. Ellard J, Wallace J. Stigma, Discrimination and Hepatitis. B: A Review. Melbourne: Australian Research Centre in. Sex, Health and Society, La Trobe University; 2013.

19. Huang J, Guan ML, Balch J. Survey of hepatitis B knowledge and stigma among chronically infected patients and un infected persons in Beijing, China. Liver Int 2016;36:1595-1603.

20. Valizadeh L, Zamanzadeh V, Bayan iM, Zabihi A. The Social Stigma Experience in Patients With Hepatitis B Infection: A Qualitative Study.Gastroenterology Nursing. 2017;40:143-150

21. Leng $A$, Li $Y$, Wangen $K R$, Nicholas $S$, Maitland $E$, Wang J. Hepatitis B discrimination in everyday life by rural migrant workers in Beijing. Hum Vaccine Immun Other 2016; 12:1164-1171.

22. Guirgis M, Yan K, Bu Y, Zekry A. General practitioners' knowledge and management of viral hepatitis in the migrant population. Internal Med J 2012;42:497-504.

23. Keskin G, Gumus AB, Orgun F. Quality of life, depression, and anxiety among hepatitis B patients. Gastroenterol Nurs 2013;36:346-356

24. Ozkan M, Corapcioglu A, Balcioglu I. Psychiatric morbidity and its effect on the quality of life of patients with chronic hepatitis $B$ and hepatitis C. Int J Psychiatry Med 2006;36:283-297.

25. Uçmak H, Ergün UG, Çelik M, Assessment of the Life Quality in Inactivated HBsAg Carriers. Viral Hepat J 2007;12:5-13.

26. 26 Yang T, Wu M-C. Discrimination against hepatitis B carriers in China. The Lancet 2011;378.

27. Wallace J, McNally S, Richmond J, Hajarizadeh B, Pitts M Managing chronic hepatitis B: A qualitative study exploring the perspectives of people living with chronic hepatitis B in Australia. BMC Research Notes 2011;4.

28. Melbourne: Australian Research Centre in Sex, Health\&Society Stigma, discrimination and hepatitis B: A Review of Current Research; 2013

29. Chao J, Chang E, So S. Hepatitis B and liver cancer knowledge and practices among health care and public health professionals in China: a cross-sectional study. BMC Public Health 2010;10:98. 
30. Mohamed R, NgCJ, Tong WT, Abidin SZ, Wong LP, Low WY. Knowledge, attitudes and practices among people with chronic hepatitis B attending a hepatology clinic in Malaysia: A cross sectional study. BMC PublicHealth 2012;12:601.

31. Li D, Tang T, Patterson M, Ho M, Heatcote J, Shah H. The impact of hepatitis B knowledge and stigma on screening in Canadian Chinese persons. Can J Gastroenterol 2012;26:597-602.

32. Tran TT. Understanding cultural barriers in hepatitis B virus infection. Cleveland ClinJMed 2009;76:10-13.

33. Li G, Wang G, Hsu F, Xu J, Pei X, Zhao B, Shetty A. Effects of Depression, Anxiety, Stigma, and Disclosure on Health-Related Quality of Life among Chronic Hepatitis B Patients in Dalian, China, The American Journal of Tropical Medicine and Hygiene 2020:102:988-994.
34. Rafique I, Saqib MAN, Siddiqui S. Experiences of stigma among hepatitis B and C patients in Rawalp indiand Islamabad. East Mediterr Heal J 2014;20:796.

35. Cotler SJ, Cotler S, Xie H, Luc BJ, Layden TJ, Wong SS. Characterizing hepatitis B stigma in Chinese immigrants. Viral Hepat J 2012;19:147-152.

36. Adjei CA, Stutterheim ES, Naab F, Ruter RA. Chronic Hepatitis B stigma in Ghana: a qualitative study with patients and providers. BMJ Open 2019;9:e025503.

37. Vu L, Gu Z, Walton J, Peet A, Dean J, Dunne M, Debbattista J. Hepatitis B knowledge, testing, and Vaccination Among Chinese and Vietnamese Adults in Australis. Asia Pac J Public Health 2012; 24:374-384 